\title{
Male Involvement in Family Planning: An Integrative Review
}

\author{
Faeda Ayed Eqtait1, Lubna Abushaikha² \\ ${ }^{1}$ School of Nursing, Arab American University, Jenin, Palestine \\ ${ }^{2}$ School of Nursing, The University of Jordan, Amman, Jordan \\ Email: faeda.eqtait@aaup.edu, 1.abushaikha@ju.edu.jo
}

How to cite this paper: Eqtait, F.A. and Abushaikha, L. (2019) Male Involvement in Family Planning: An Integrative Review. Open Journal of Nursing, 9, 294-302. https://doi.org/10.4236/ojn.2019.93028

Received: February 3, 2019

Accepted: March 11, 2019

Published: March 14, 2019

Copyright $\odot 2019$ by author(s) and Scientific Research Publishing Inc. This work is licensed under the Creative Commons Attribution International License (CC BY 4.0).

http://creativecommons.org/licenses/by/4.0/

\section{(c) (i) Open Access}

\begin{abstract}
Purpose: The purpose of this review was to identify evidence about determinants of male engagement in family planning. Methods: An integrative review was used to assess the determinants of male engagement in family planning. Data search was between 2014 and 2019 using Google Scholar, Scopus, Web of Science, Science Direct, Pub Med, Medline, CINAHL, EBSCO, Cochrane, and EBSCO host. A total of 14 articles met the eligibility criteria. Results: The fourteen reviewed articles were adopted with mixed method designs, randomized controlled trial, quazi-experimental, and survey. Themes were: determinant of male engagement in family planning, women perception of male enrolment in family planning, and methods to enhance male use of family planning. Conclusion: Religion, large family size, culture, fear of side effect, access and exposure to information, attitudes, norms and self-efficacy and interaction with a health care provider are determinants of male involvement in family planning use. Interventional programs by health care providers and intensive education to men will positively increase prevalence of family planning use. It's recommended to involve religious leaders in education. Implication: More attention is needed at community and governmental level to identify strategies to promote gender equity, shared decision making, shared responsibility and positive participation of men, empowering women, and to increase effectiveness of male participation.
\end{abstract}

\section{Keywords}

Family Planning, Reproductive Health, Contraception, Birth Control, Unplanned Pregnancy, Unintended Pregnancy and Birth Spacing

\section{Introduction}

Reproductive health addresses the reproductive processes, functions and system 
at all stages of life [1]. Reproductive health implies that people are able to have a responsible, satisfying and safe sex life and that they have the capability to reproduce and the freedom to decide if, when, and how often to do so [1]. The United Nations Population Fund (UNFPA) defines family planning as methods and information that enable persons to make decisions when to have children [2]. Both men and women have the right to be informed about safe, effective, affordable and acceptable methods of family planning, and they have the right to choose and decide the most affordable methods of family planning [1]. Reproductive health is an essential component of general health; family planning is one of the most basic and essential healthcare services that can promote and ensure reproductive health [3]. This includes a broad spectrum of contraceptive methods including chemical contraceptive methods like spermicide (foam, jelly, or tablet), mechanical contraceptive methods like intrauterine device (IUDs), condoms and diaphragm, and natural methods like fertility awareness [2]. Family planning also includes information about how to become pregnant when it is desirable, as well as treatment of infertility [2].

Family planning programs were established in most countries between 1950 and 1980, which represented one of the most important social experiments after World War II. In 2007, the World Bank published the global family planning revolution as it recognized rapid population growth as a barrier in achieving development [1] [4]. Family planning programs started to enter the third world countries during the 1960s. Moreover, more attention was given to the issue of family planning after the Cairo conference in 1994 [5].

\section{Materials and Methods}

In this review, the search was performed by different international databases including Google Scholar, Scopus, Web of Science, Science Direct, Pub Med, Med line, CINAHL, EBSCO, Cochrane, and EBSCO host using the keywords of "family planning", "reproductive health", "contraception", "birth control", "unplanned pregnancy" "unintended pregnancy" and "birth spacing". Initially, searching for these key words was done in separated for each. Then new search added a new keyword until including all keywords. Later, these words were searched in combination with each other, starting with search process targeted primary resources with no geographical limits. Boolean operators (AND, OR) have been applied to enlarge or exclude key words to narrow the search results. However, the searching process was limited to following inclusion criteria: 1) written in English, 2) published between 2014 and 2019,3) specifically related to family planning, and 4) no restriction on article type. The intervention is the use of family planning methods by men. The quantitative and qualitative, and descriptive studies were considered and summaries to identify the best evidence.

However, review papers and incomplete reports in the form of editorials, opinion pieces, and conference abstracts have been excluded. Furthermore, a total of 1128 articles were retrieved and the initial evaluation for their titles abstracts 
took place. After evaluating and removing the duplicated articles, only 262 were found to be related to the topic of interest. Then, related articles were printed and read in full, following a secondary evaluation, 14 articles were exactly identified to cover the inclusion criteria. As a result, those fourteen articles were included in this review (see Figure 1). Among the 14 articles, 1 article was randomized control trial, 1 article was mixed method approach, 7 were cross sectional survey, 2 article was qualitative, 1 article was quasi-experimental, 1 nonequivalent, post-intervention only control group design and 1 was longitudinal study. The findings of each study were considered with codes for identification from the literature, summarization, synthesis and inferences, and discussion of findings for clarifying the interpretation themes.

Articles selected for retrieval were assessed for methodological validity by two independent reviewers prior to inclusion in the review. Critical appraisal assessment and review was done with agreement between the reviewers and a third reviewer was consulted when needed. Data was extracted from the literature included in the review using standardized data extraction using specific details about the interventions, populations, study methods and outcomes of significance to the aim of the review. Then to display the data, all summarized pages were collected in a one matrix by using word sheet.

\section{Results}

Fourteen relevant articles have been reviewed. From each article the following data have been extracted: study purpose, design, sample, and findings (Table 1).

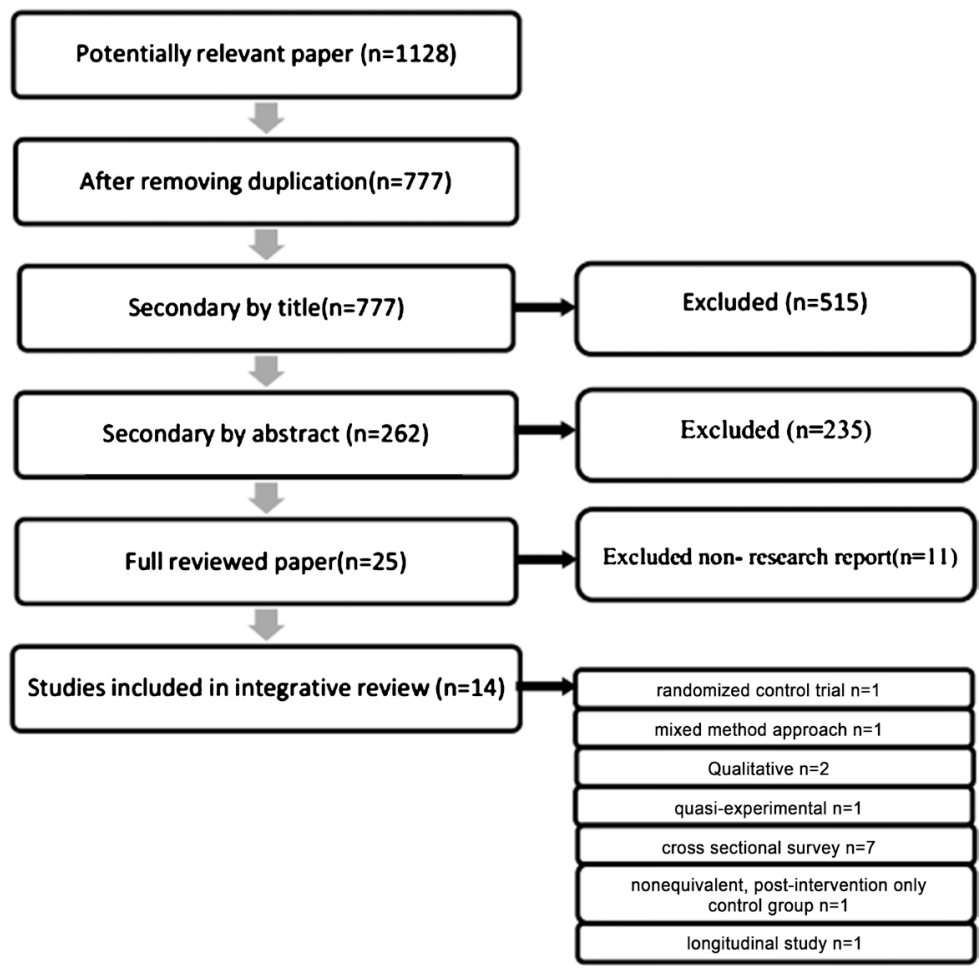

Figure 1. Search strategy and outcomes. 
Table 1. A summary of the characteristics of the included articles.

\begin{tabular}{|c|c|c|c|c|c|}
\hline Author & Purpose & Sample size & Intervention & Design & Main finding \\
\hline $\begin{array}{l}\text { Bishwajit, Tang, } \\
\text { Yaya, Ide, Wang and } \\
\text { Feng (2017) [6] }\end{array}$ & $\begin{array}{l}\text { To investigate factors associated } \\
\text { with male involvement in } \\
\text { reproductive health among } \\
\text { Bangladeshi men }\end{array}$ & $\mathrm{n}=1196$ & $\begin{array}{l}\text { Bangladesh Demographic and } \\
\text { Health Survey (BDHS) data was } \\
\text { used. Participants were married } \\
\text { men aged } 15 \text { - } 69 \text { years }\end{array}$ & $\begin{array}{l}\text { Health Survey } \\
\text { Cross section }\end{array}$ & $\begin{array}{l}\text { Findings indicated that only } 40 \% \text { of } \\
\text { men were found to be active about } \\
\text { partners' reproductive healthcare }\end{array}$ \\
\hline $\begin{array}{l}\text { Masters, Morrison, } \\
\text { Querna, Casey and } \\
\text { Beadnell (2017) [7] }\end{array}$ & $\begin{array}{l}\text { To examine men's intentions to } \\
\text { discuss birth control with a } \\
\text { female partner }\end{array}$ & $\mathrm{n}=372$ & $\begin{array}{l}\text { Online survey. Participants } \\
\text { were men aged } 18-25 . \\
\text { Questions were attitudes } \\
\text { toward, norms regarding and } \\
\text { self-efficacy }\end{array}$ & survey & $\begin{array}{l}\text { Results showed that men's intention } \\
\text { to discuss birth control is affected by } \\
\text { attitudes, norms and self-efficacy } \\
\text {-The more strongly men endorsed a } \\
\text { traditional masculinity sexual script, } \\
\text { are less likely intend to discuss birth } \\
\text { control }\end{array}$ \\
\hline
\end{tabular}

\begin{tabular}{llll}
\hline Ochako, & $\begin{array}{l}\text { To understand the determinants } \mathrm{n}=9514 \\
\text { of modern contraceptive use }\end{array}$ & $\begin{array}{l}\text { Demographic and Health } \\
\text { Temmerman, }\end{array}$ & $\begin{array}{l}\text { Survey (DHS) (Kenya 2014) of } \\
\text { and Health }\end{array}$ \\
Mbondo and Askew & among sexually active men & men aged 15 - 54 years & Survey
\end{tabular}

men aged 15 - 54 years Survey

Results showed that place of residence, marital status, religion, wealth, interaction with a health care provider, fertility preference, number of sexual partners and access to media were all significantly associated with modern contraceptive use among sexually active men

Kabagenyi, Jennings, To examine gendered views Reid, Nalwadda, regarding factors limiting men's Ntozi and Atuyambe involvement, as evidenced by (2014) [9] partner communication, approval, support, or utilization of family planning methods

\section{$\mathrm{n}=154$}

18 focus group discussions. Purposive sample of men aged 15 - 54 and women aged 15 49 , eight key informant interviews with government and community leaders

cross-sectional Reasons for men's limited involvement qualitative in reproductive health include: side study effects of female contraceptive methods, dissatisfaction with male contraceptive choices, perceptions that family planning was a woman's domain, large family size preferences, and fear of partner sexual promiscuity

Kassa, Abajobir and To assess the level of male $\quad n=524$ Gedefaw (2014) [10] involvement in family planning services utilization and its associated factors in Debremarkos Town, Northwest Ethiopia

$\begin{array}{ll}\begin{array}{l}\text { A community-based } \\ \text { cross-sectional study. }\end{array} & \begin{array}{l}\text { community } \\ \text { based }\end{array} \\ \text { Multi-stage sampling technique. } & \text { cross-sectional } \\ \text { Semi-structured questionnaires } & \\ \text { were used } & \\ & \\ \text { Systematic review of qualitative } & \text { A systematic } \\ \text { studies published between 1994 } & \text { review of } \\ \text { until 2011. Participants were } & \text { qualitative } \\ \text { men from all cultures, ethnic } & \text { studies } \\ \text { backgrounds and religions } & \end{array}$

Results show that level of male involvement was low. Lack of al information, inaccessibility to the services and the desire to have more children were found to be the reasons for low male involvement in family planning services utilization

Hoga, Rodolpho, To explore the men's beliefs, Sato, Nunes and values, attitudes and experiences Borges (2014) [11] towards contraceptives
Findings show that: Contraceptive behavior is influenced by religious, family and social backgrounds Gendered, male-centered values predominate in contraceptive behaviors

\begin{tabular}{|c|c|c|c|c|c|}
\hline $\begin{array}{l}\text { Patra and Singh } \\
(2014)[12]\end{array}$ & $\begin{array}{l}\text { To address men's attitudes } \\
\text { towards the use and choice of } \\
\text { contraception by women in } \\
\text { India }\end{array}$ & $\begin{array}{l}\mathrm{n}=69,751 \\
\text { men of age } \\
\text { group } 15 \text { to } \\
49 \text { years } \\
\text { and } \\
\mathrm{n}=43,501 \\
\text { currently } \\
\text { married } \\
\text { men of } 15 \text { to } \\
49 \text { years age }\end{array}$ & $\begin{array}{l}\text { Data from The National Family } \\
\text { Health Survey-3 (NFHS-3). } \\
\text { Bivariate and multivariate } \\
\text { analyses are used }\end{array}$ & $\begin{array}{l}\text { National } \\
\text { Family Health } \\
\text { Survey-3 }\end{array}$ & $\begin{array}{l}\text { Results revealed the following: } \\
\text { 1. Men in India think contraception } \\
\text { is women's business, and men } \\
\text { should not have to worry about it. } 2 \text {. } \\
\text { Men believe, by using contraception, } \\
\text { women may become promiscuous. } \\
\text { 3. According to } 49 \% \text { men, a lactating } \\
\text { woman, can't become pregnant. } \\
\text { 4. Men with higher education level, } \\
\text { media exposure and with knowledge } \\
\text { of modern family planning are } \\
\text { significantly more likely to agree that } \\
\text { wife can ask her husband to use } \\
\text { condom if he has STDs (p < } 0.01 \text { ) }\end{array}$ \\
\hline
\end{tabular}




\section{Continued}

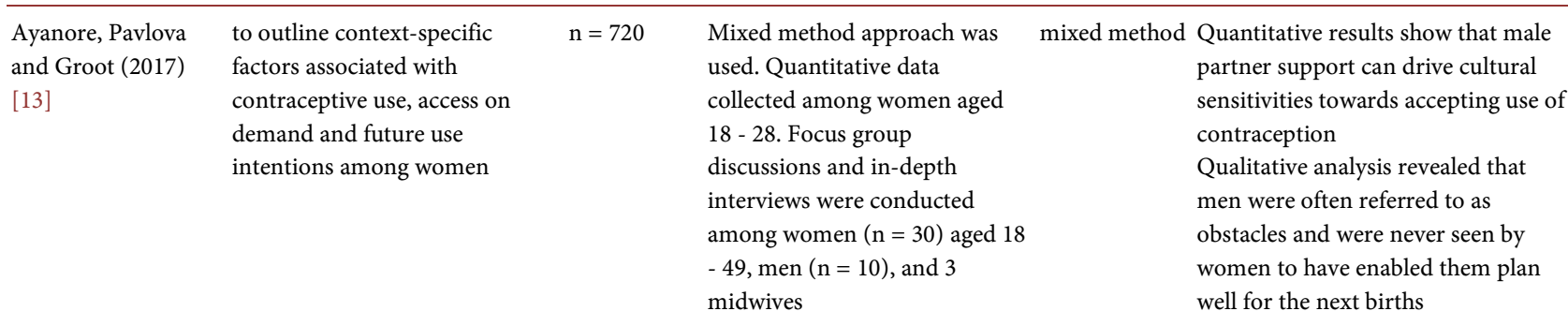

\begin{tabular}{llll}
\hline $\begin{array}{l}\text { Okigbo, Speizer, } \\
\text { Domino, Curtis, }\end{array}$ & $\begin{array}{l}\text { to examine the association } \\
\text { between changes in gender }\end{array}$ & $\mathrm{n}=16,118$ & $\begin{array}{l}\text { De-identified longitudinal data multilevel } \\
\text { by the Measurement, Learning longitudinal potential to increase the prevalence }\end{array}$ \\
$\begin{array}{l}\text { Halpern and Fotso } \\
\text { norms and modern }\end{array}$ & $\begin{array}{l}\text { \& Evaluation project. Data were } \\
\text { study }\end{array}$
\end{tabular}

(2018) [14] contraceptive use over time among women in urban Nigeria collected from women aged 15 -

49 living in six cities in Nigeria.

Again from 10,672 of the same

women ( $34 \%$ attrition rate)
Speizer, Corroon, To examining men's exposure to $n=2270$

Calhoun, Gueye and family planning (FP) program

Guilkey (2018) [15] activities in urban Senegal and determining whether exposure is associated with reported FP use and discussion of family planning with female partners

Two cross-sectional surveys of
men in four urban sites of
Senegal. Men ( 15 - 59 years) in
a random sample of households
from study clusters were
approached and asked to
participate in a survey

two Study finding indicated that: cross-sectional -Men who were exposed to a surveys religious leader speaking about FP were more likely to report using FP and discussing FP with their partner - Radio activities and television exposure was associated with FP use. - There was an association between community-based activities and these outcomes

Raj, Ghule, Ritter, Battala, Gajanan, Nair and Saggurti (2016) [16]

\section{To evaluate CHARM}

[Counseling Husbands to and Marital equity], delivered to married men
Achieve Reproductive health

\section{$\mathrm{n}=1081 \quad$ Two-armed cluster randomized cluster} controlled trial was conducted randomized with young married couples, from controlled 50 geographic clusters. Participants trial were surveyed at baseline and 9 and 18-month follow-up. Surveys were administered in an interview format

Sakara, Namong and To examines the factors, which $n=160$ Badu-Nyarko (2014) inhibit male active involvement [17]

survey in family planning practice, and the strategies that can be implemented to make males effective and reliable partners in family planning practice
Purposive and simple random technique was used. Data was collected by using focus group discussion, structured interview and questionnaire. Participants were married men (aged 24 to 65 years)
Study finding revealed that the CHARM intervention, appears to be an effective approach to engage men in family planning, improve marital contraceptive communication and use, and reduce male perpetration of sexual IPV

Findings revealed that men perceive family planning as a preserve for women.

Factors against male involvement include lack of attractive, safe and convenient male contraceptives, disapproval of modern contraceptives by their religions the catholic and Islamic faiths, pressure to have many children Strategies for effective male involvement include intensive education on benefits, misconceptions The target for education should include religious leaders, chiefs and opinion leaders

\begin{tabular}{|c|c|c|c|}
\hline $\begin{array}{l}\text { Underwood and } \\
\text { Kamhawi (2014) } \\
{[18]}\end{array}$ & $\begin{array}{l}\text { To assess the effects of a } \\
\text { communication intervention } \\
\text { designed to enhance Jordanian } \\
\text { religious leaders' (RLs) } \\
\text { communication about family } \\
\text { health }\end{array}$ & $\mathrm{n}=840$ & $\begin{array}{lll}\begin{array}{l}\text { Authors used self-administered } \\
\text { questionnaires at baseline and } 6\end{array} & \begin{array}{l}\text { nonequivalent, } \\
\text { posteintervent }\end{array} & \text { recalled messages were more likely } \\
\text { months post-intervention. } 22 & \text { ion only } & \text { to report taking relevant actions } \\
\text { workshops held for male } & \text { control group } & \\
\text { preachers (aged } 18 \text { and older). } & \text { design } & \\
13 \text { were randomly selected. } & & \\
\text { Eight workshops held for } & & \\
\text { female preachers (aged } 18-50) & \end{array}$ \\
\hline
\end{tabular}




\section{Continued}

Tilahun, Coene,

Temmerman and

Degomme (2015)

[19]

\author{
To measure the effect of a $\quad n=811$ \\ six-month-long family planning \\ education program on male \\ involvement in family planning, \\ as well as on couples' \\ contraceptive practice
}

\author{
Study was conducted in Jimma quasi-experim Intervention increase in the men's \\ Zone. A multi-stage sampling ental intention to go to family planning \\ design was used. Authors used a \\ services with their spouses \\ From the women's perspective, it \\ appeared that husbands of women \\ who were already contraceptive \\ users were more involved
}

Then, authors compared articles to identify themes. Review articles show that law percentage of men involved in family planning practices [6]. From women perspectives men were seen as an obstacle and never enabled them to plan their next pregnancy [13]. Men engagement in family is affected by different factors [7] [8] [9] [10]. Attitudes, norms and self-efficacy were each positively associated with men's intention to discuss birth control [7].

The more strongly men endorsed a traditional masculinity sexual script; the less likely they were to intend to discuss birth control [1]. Determinants of modern contraceptive use among sexually active men $(n=9514)$ were: region of residence, marital status, religion, wealth, interaction with a health care provider, fertility preference, number of sexual partners and access to media [8]. Men's (n $=154$ ) identified reasons for limited involvement in reproductive health include: side effects of female contraceptive methods, dissatisfaction with male contraceptive choices, perceptions that family planning was a woman's domain, large family size preferences, and fear of partner sexual promiscuity [9]. Male ( $\mathrm{n}=$ 524) involvement in family planning is affected by lack of information, inaccessibility to the services and the desire to have more children [10]. Contraceptive behavior is influenced by religious, family and social backgrounds [11]. Gendered male centered values predominate in contraceptive behaviors [11]. In India, men's $(n=69,751)$ attitude about family planning revealed that they think contraception is women's business, and men should not have to worry about it, by using contraception, women may become promiscuous and lactating woman, can't become pregnant [16]. Women $(n=720)$ considered male partner support can drive cultural sensitivities towards accepting use of contraception [13]. For women in Nigeria $(n=16,118)$ gender-equitable norms have the potential to increase the prevalence of modern contraceptive use [14].

There was an association between community-based activities and sue of family planning. In Senegal, men $(n=2270)$ who were exposed to a religious leader speaking favorably about family planning were more likely to report using family planning and discussing family planning with their spouses [15]. Radio activities and television exposure was associated with family planning use [19]. Married men $(\mathrm{n}=1081)$ who were exposed to CHARM (Counseling Husbands to Achieve Reproductive health and Marital equity) intervention revealed that it was an effective approach to engage men in family planning, improve marital contraceptive communication and use [16]. CHARM also reduce male perpetration of sexual intimate partner violence [16]. Men with higher education level, 
media exposure and knowledge of modern family planning are significantly more likely to agree that wife can ask her husband to use condom if he has STDs [16]. Strategies to increase men involvement in family planning include intensive education for men, religious leaders, chiefs and opinion leaders [17]. Mosque goers $(\mathrm{n}=840)$ who recalled messages were more likely to report taking relevant actions [18].

\section{Discussion}

In this integrative review, common themes emerged were determinant of male engagement in family planning, women perception of male enrolment in family planning, and methods to enhance male use of family planning. Review studies revealed that male intention to discuss family planning is affected by their attitudes; norms and self-efficacy were each positively associated with men's intention to discuss birth control [7]. At the same time region of residence, marital status, religion, wealth, interaction with a health care provider, fertility preference, number of sexual partners and access to media are also important factors that affect male use of family planning [8]. Moreover, side effects of female contraceptive methods, dissatisfaction with male contraceptive choices, perceptions that family planning as a woman's domain, large family size preferences are relevant factors [9]. Family planning also affected by male attitude as they think contraception is women's business, and men should not have to worry about it [12].

For women perception of male enrolment in family planning they consider gender-equitable norms [14] and male partner support can increase the prevalence of modern contraceptive use [13]. This review also pointed some measures to increase use and communication of family planning among men. Higher education level, exposure to media and knowledge of modern family planning are significantly improving communication with their partner [12]. Community-based activities, exposure to a religious leader speaking favorably about family planning [15] [20] and counseling programs for husbands are effective approach to engage men in family planning [16].

Therefore, identification of male determinant of family planning, factors affecting family planning use, male and women perception about this issue will help health care providers where to start their intervention with aim to increase prevalence of family planning among male and female and to help them to reach shared decision.

\section{Conclusion}

The recognition of the possible determinants and barriers including identification of men's negative health beliefs regarding contraceptive services can be used to develop effective male-involvement in family planning. More attention is needed at community and governmental level to identify strategies to promote gender equity and shared decision making, shared responsibility and positive 
participation of men, empowering women, and to increase effectiveness of male participation. Male-focused interventions should be encouraged instead of women focused programs as family planning should be considered shared responsibility.

\section{Recommendations}

Attention is needed at community and governmental level to identify strategies to promote gender equity, shared decision making, shared responsibility, positive participation of men, empowering women, and to increase effectiveness of male participation in family planning use. Male focused programs, intensive education for men and religious leaders should be considered.

\section{Conflicts of Interest}

The authors declare no conflicts of interest regarding the publication of this paper.

\section{References}

[1] http://www.who.int/reproductivehealth/topics/family_planning/en/

[2] https://www.unfpa.org/family-planning

[3] http://www.uniteforsight.org/women-children-course/reproductive-health

[4] https://www.fpa.org.uk/factsheets/history-family-planning-services

[5] Robinson, W.C. and Ross, J.A. (Eds.) (2007) The Global Family Planning Revolution: Three Decades of Population Policies and Programs. The World Bank, Washington DC. https://doi.org/10.1596/978-0-8213-6951-7

[6] Bishwajit, G., Tang, S., Yaya, S., Ide, S., Fu, H., Wang, M. and Feng, Z. (2017) Factors Associated with Male Involvement in Reproductive Care in Bangladesh. BMC Public Health, 17, 3. https://doi.org/10.1186/s12889-016-3915-y

[7] Masters, N.T., Morrison, D.M., Querna, K., Casey, E.A. and Beadnell, B. (2017) Correlates of Young Men's Intention to Discuss Birth Control with Female Partners. Perspectives on Sexual and Reproductive Health, 49, 37-43. https://doi.org/10.1363/psrh.12005

[8] Ochako, R., Temmerman, M., Mbondo, M. and Askew, I. (2017) Determinants of Modern Contraceptive Use among Sexually Active Men in Kenya. Reproductive Health, 14, 56. https://doi.org/10.1186/s12978-017-0316-3

[9] Kabagenyi, A., Jennings, L., Reid, A., Nalwadda, G., Ntozi, J. and Atuyambe, L. (2014) Barriers to Male Involvement in Contraceptive Uptake and Reproductive Health Services: A Qualitative Study of Men and Women's Perceptions in Two Rural Districts in Uganda. Reproductive Health, 11, 21. https://doi.org/10.1186/1742-4755-11-21

[10] Kassa, M., Abajobir, A.A. and Gedefaw, M. (2014) Level of Male Involvement and Associated Factors in Family Planning Services Utilization among Married Men in Debremarkos Town, Northwest Ethiopia. BMC International Health and Human Rights, 14, 33. https://doi.org/10.1186/s12914-014-0033-8

[11] Hoga, L.A., Rodolpho, J.R., Sato, P.M., Nunes, M.C. and Borges, A.L. (2014) Adult Men's Beliefs, Values, Attitudes and Experiences regarding Contraceptives: A Systematic Review of Qualitative Studies. Journal of Clinical Nursing, 23, 927-939. https://doi.org/10.1111/jocn.12262 
[12] Patra, S. and Singh, R.K. (2014) Men's Attitude towards the Use of Family Planning Methods by Women in India: An Exploratory Study. Indian Journal of Health and Wellbeing, 5, 209.

[13] Ayanore, M.A., Pavlova, M. and Groot, W. (2017) Context-Specific Factors and Contraceptive Use: A Mixed Method Study among Women, Men and Health Providers in a Rural Ghanaian District. African Journal of Reproductive Health, 21, 81-95. https://doi.org/10.29063/ajrh2017/v21i2.10

[14] Okigbo, C.C., Speizer, I.S., Domino, M.E., Curtis, S.L., Halpern, C.T. and Fotso, J.C. (2018) Gender Norms and Modern Contraceptive Use in Urban Nigeria: A Multilevel Longitudinal Study. BMC Women's Health, 18, 178. https://doi.org/10.1186/s12905-018-0664-3

[15] Speizer, I.S., Corroon, M., Calhoun, L.M., Gueye, A. and Guilkey, D.K. (2018) Association of Men's Exposure to Family Planning Programming and Reported Discussion with Partner and Family Planning Use: The Case of Urban Senegal. PloS ONE, 13, e0204049. https://doi.org/10.1371/journal.pone.0204049

[16] Raj, A., Ghule, M., Ritter, J., Battala, M., Gajanan, V., Nair, S. and Saggurti, N. (2016) Cluster Randomized Controlled Trial Evaluation of a Gender Equity and Family Planning Intervention for Married Men and Couples in Rural India. PLoS ONE, 11, e0153190. https://doi.org/10.1371/journal.pone.0153190

[17] Sakara, A., Namong, M. and Badu-Nyarko, S.K. (2014) Strategies for Effective Male Involvement in Family Planning Practice in Wa District, Upper West Region of Ghana. International Journal of Current Research, 6, 5592-5599.

[18] Underwood, C.R. and Kamhawi, S.S. (2014) Friday Sermons, Family Planning and Gender Equity Attitudes and Actions: Evidence from Jordan. Journal of Public Health, 37, 641-648. https://doi.org/10.1093/pubmed/fdu090

[19] Tilahun, T., Coene, G., Temmerman, M. and Degomme, O. (2015) Couple Based Family Planning Education: Changes in Male Involvement and Contraceptive Use among Married Couples in Jimma Zone, Ethiopia. BMC Public Health, 15, 682. https://doi.org/10.1186/s12889-015-2057-y

[20] Arousell, J. and Carlbom, A. (2016) Culture and Religious Beliefs in Relation to Reproductive Health. Best Practice \& Research Clinical Obstetrics \& Gynaecology, 32, 77-87. https://doi.org/10.1016/j.bpobgyn.2015.08.011 